\title{
滑空機操縦における眼球運動の特性
}

\author{
$\bigcirc$ 市川 博（産能短期大学）、杉山篤司、富島修司、 \\ 梅村 守 (東京理科大学)
}

\section{Characteristics of Eye Movement on Glider Pilots}

H.Ichikawa ( Sanno College, Jiyugaoka ), A.Sugiyama, S.Tomisima, M.Umemura (Science Univ. of Tokyo)

\section{1.はじめに}

航空機の操縦者は、外部視界や飛行計器に 表示される航空機の姿勢、高度、速度などの 情報を入手している。また、聴覚や体性感覚 などによる振動や傾きの情報も入手してい る。しかし、その情報の大部分は外部視界や 飛行計器などから得られる機体の状態や周囲 の状海などの視覚情報である。操縦者はこの 無数の視覚情報からその時々の状況判断を行 い操縦している。視覚情報に関する研究は、 眼球運動測定装置（アイカメラ）を用いて多 〈報告されている1)。しかし、それらの多く はフライトシミュレータを用いたものであ り、実機によるものはほとんどない。また、 研究の対象は動力を装備した航空機であり、 動力を持たない滑空機の例はない。

そこで本研究は滑空機操縦における視線の 動きをアイカメラを用いて分析し、外界から 得られた視覚情報の処理過程の…面を明らか にすることを目的とする。また、滑空機操縦 における習熟者と末習熟者の比較もあわせて 検討する。

\section{2. 実験方法}

被験者：大学航空部に所属する大学生 5 名で ある。各被験者の特性を表 1 に示す。 测定方法：眼球運動測定装置（ナック社製 $E M R-7$ 型）を用いて眼球運動を測定し た。視線停留時間は 0.066 秒以上で視角 2 度以 内の視線移動とした。
表 1 被験者の特性

\begin{tabular}{|c|c|c|c|c|}
\hline 被験者 & 性別 & 年齡 & 飛行時間 $(\mathrm{h})$ & 資格有無 \\
\hline 被験者 $\mathrm{A}$ & 男性 & 20 & 3 & なし \\
\hline 被験者 $\mathrm{B}$ & 男性 & 20 & 11 & なし \\
\hline 被験者 $\mathrm{C}$ & 男性 & 21 & 21 & なし \\
\hline 被験者 $\mathrm{D}$ & 男性 & 22 & 47 & 自家用操縦士 \\
\hline 被験者 $\mathrm{E}$ & 男性 & 23 & 105 & 自家用操縦士 \\
\hline
\end{tabular}

実験内容：滑空機はグローブ社製 T W I N ・ A S T I R を用い、前席に被験者が搭乗し、 安全確保のため後席に教官が搭乗した。実験 に用いた飛行課目は、離陸・水平直線滑空・ 左旋回・右旋回・着陸の合計 5 課目とした。

\section{3. 結果および考察}

\section{1 視線の動向}

習熟者（被験者 $\mathrm{E} ）$ と末習熟者（被験者 A）の右旋回中の視線の動问を図 1 に示す。 ただ○の位置は視線停留点、○の大きさは 視線停留時間の長さを表している。両被験者 とも視線停留点は飛行前方、旋回方向、飛行 計器の 3 点であることがわかる。また、視線 停留時間は被験者Eが飛行前方に集中してい るのに対し、被験者 $\mathrm{A}$ は飛行計器（速度計） に集中していることがわかる。動力のない滑 空機操縦では機体の姿勢のチェックにより、 飛行速度をコントロールしている。機体の姿 勢チェックは機体の先端部分（ノーズ）と地 平線の関係から行っている。この結果は、習 熟者は飛行前方より地平線とノーズの位置関 


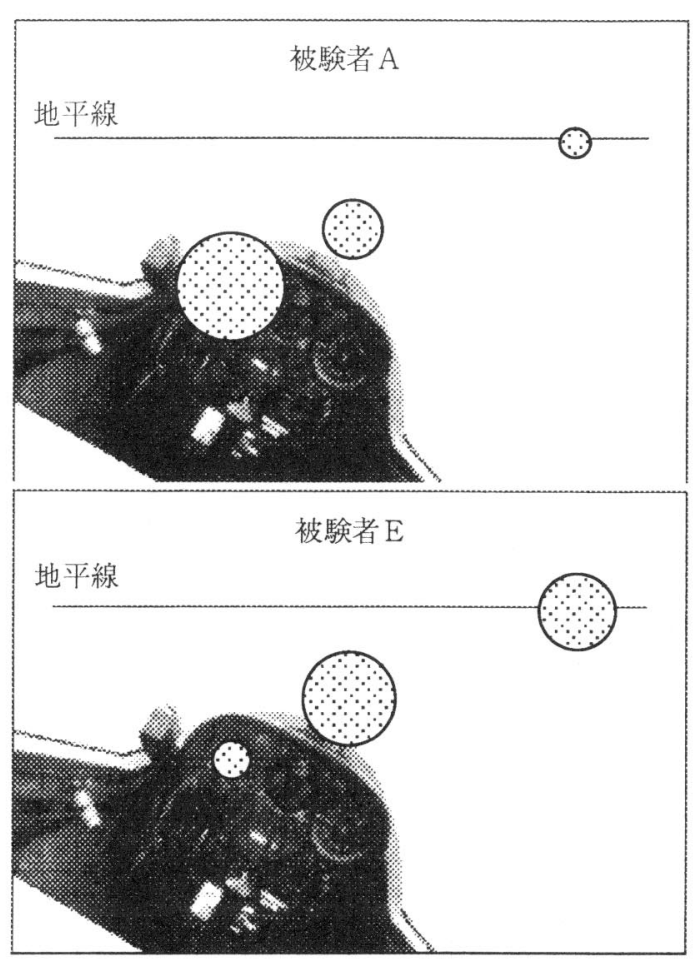

図 1 視線の動向（右旋回）

係から飛行速度をコントロールしているのに 対し、未習熟者は地平線とノーズの位置関倸 から機体の姿勢を読み取ることが困難で、計 器に頼って速度をコントロールしていると言 える。

\section{3 . 2 視線停留時間}

各被験者の飛行時間と視線停留時閒の関係 を図2 に示す。飛行時間が長くなるにした がって視線停留時間が減少していく傾向が見

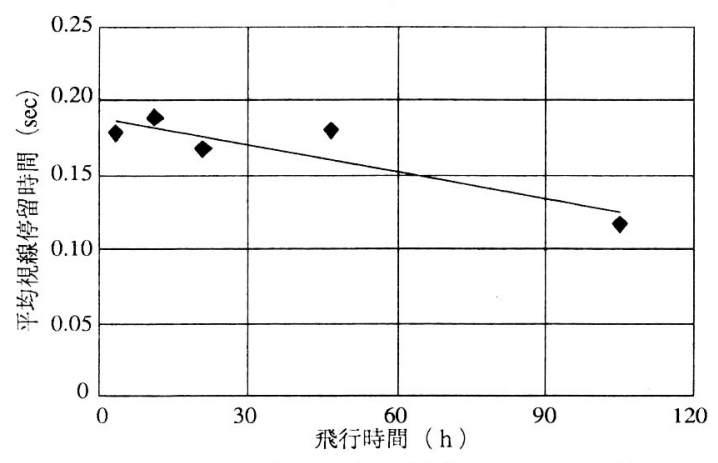

図 2 飛行時間と平均停留時間の関係

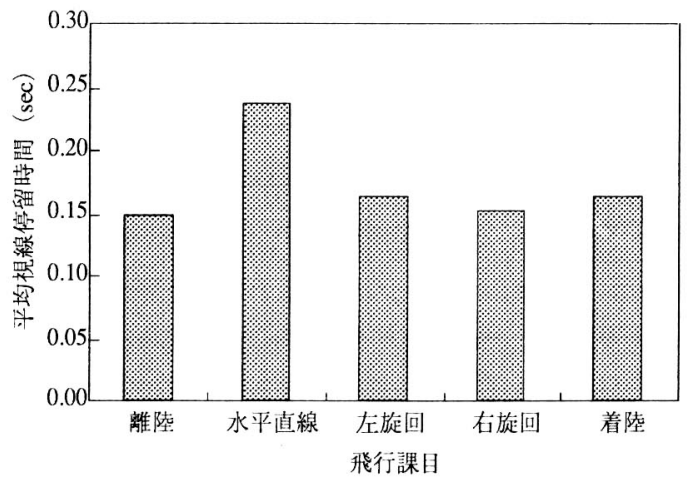

図3飛行課目と平均停留時間の関係（全被験者平均）

られる。習熟者は視覚情報を瞬時に判断して いるのに対し、未習熟者は視覚情報を把握す るのに長い時間がかかることを示している。

3. 3 飛行課目と視線停留時間の関係 飛行課目と視線停留時間の関係を図 3 に示 す。水平直線飛行は他の飛行課目とくらべ、 視線停留時間が長くなっている。これは、水 平直線飛行の主なチェック項目が飛行速度で あることから、ノーズと地平線の位置関係を 確認することが多いためと考えられる。

\section{4.おわりに}

アイカメラを用いて滑空機操縦における視 線移動に関する実験の結果、以下のことが明 らかになった。

1) 習熟した操縦者ほど計器に頼らず、ノー ズと地平線の位置関係から滑空機の姿勢を判 断し、速度コントロールを行っている。

2) 習熟者ほど視線停留時間が減少し、視覚情 報の把握が早くなる傾向が見られた。

3）水平直線滑空時には、他の飛行課目より 視覚情報が少なく、視線停留時間が長い傾向 が観察された。

\section{【参考文献】}

1）西修二, 大久保堯夫：フライトシミュ レータを用いた操縦者の視線移動に関する研 究, 人間工学, 31(3),225-233,1995. 